\title{
Stem Barks and Roots Extravitism in Ekiti State Nigeria: Need for Conservation as a Sustainable Innovation in Healthcare Management in Rural Areas
}

\author{
Joshua Kayode ${ }^{1,}$, Michael Ayorinde Omotoyinbo ${ }^{1}$, Modupe Janet Ayeni ${ }^{1}$, Ayodele Adelusi Oyedeji ${ }^{2}$ \\ ${ }^{1}$ Department of Plant Science, Ekiti State University, Ado-Ekiti, Nigeria \\ ${ }^{2}$ Department of Biological Sciences, Niger Delta University, Wiberforce Island, Nigeria
}

Email address:

joshua.kayode@eksu.edu.ng (J. Kayode)

To cite this article:

Joshua Kayode, Michael Ayorinde Omotoyinbo, Modupe Janet Ayeni, Ayodele Adelusi Oyedeji. Stem Barks and Roots Extravitism in Ekiti State Nigeria: Need for Conservation as a Sustainable Innovation in Healthcare Management in Rural Areas. American Journal of BioScience. Vol. 3, No. 2, 2015, pp. 28-33. doi: 10.11648/j.ajbio.20150302.11

\begin{abstract}
A combination of field surveys and direct observation was used to identify botanicals whose stems and/or roots were extracted for healthcare purposes in the rural communities of Ekiti State, Nigeria. Diverse number of species was identified as being used for health care by respondents in the study area. The respondents' consensus factor which specifies the agreement degree of the respondents revealed that their preference for healthcare maintenance was skewed towards the use of botanicals rather than the orthodox drugs. Respondents' fidelity level was determined and the results obtained revealed that the botanicals were perceived as safe, cheap, readily available with little or no side effects. Considerable proportions of these botanicals were not cultivated and their collection pattern was mostly annihilative and unsustainable. Thus they were mostly rare on the abundance scale used in this study. Most of the uncultivated species were indigenous tree species that has forest as their primary source. With increasing and unprecedented deforestation rate in the study area, there is the need for conservation of these species.
\end{abstract}

Keywords: Stem Barks, Roots, Extravitism, Conservation, Sustainable Innovation, Healthcare

\section{Introduction}

Ekiti State (Longitude $4^{\circ} 5^{\prime}$ and $5^{\circ} 4^{\prime}$ East, and Latitude $7^{\circ} 45^{\prime}$ and $8^{\circ} 5^{\prime}$ North) is located in the south western part of Nigeria. Majority of the Ekitis, like other Yoruba tribes, live mainly in the rural areas. Over $70 \%$ of the population in the state resides in the rural areas. [1], [2] asserted that most of these people depend on the environment for the maintenance of their health.

Recently a resurgence of interest on the use of botanicals for health management and maintenance evolved in Nigeria [3]. This is considered necessary particularly now that the forest that constituted the primary source of these botanicals is seriously under threat. Recent initiatives revealed that Nigeria has lost most of its total forest cover. The rate of deforestation in the country has been estimated to be at an average of about 3.5 per cent per annual. Deforestation at this rate translates to loss of 350,000 to 400,000 ha of Nigeria's forest land per year [4].

In view of the above, a number of studies are being carried out in the Department of Plant Science, Ekiti State University, Ado-Ekiti, Nigeria to document botanicals that have medicinal value with a view to determining their abundance, identifying the endangered species and evolving strategies that would conserve the identified rare species thus enhancing their sustainability for the present and future generations. The study being reported here aimed at compiling the list of botanicals whose stems and/or roots are extracted for medicinal purposes in the state and propose strategies that would enhance their conservation.

\section{Materials and Methods}

The methods of $[5,6,7]$ which consisted of a combination of social surveys and direct field observation was used in this study. Ekiti State was divided into three zones based on the existing political delineation. In each zones, 10 communities that were still relatively free from urban influence were selected.

In each community, 10 indigenes that had maintained 
continuous domicile for a period of 10 years and above were selected and interviewed with the aid of a semi-structured questionnaire matrix. The interviews were conducted with a fairly open framework that allowed for focused, conversational and two-way communication as suggested by [8].

Botanicals whose stems and/or roots were extracted and used for medicinal purposes were identified and their voucher specimens were collected. The sources of such botanicals and their methods of utilization were also identified. The abundance of the species was also determined using the time taken to physically come in contact with the sample of the botanical within the aboriginal plant communities in the community. Where a sample was sighted within 20 minutes, it was considered as very abundant, it was abundant when sighted within 21-60 minutes but rare when it takes more than 60 minutes.

The fidelity level (FL) of the species was determined to establish the level of awareness of the medicinal suitability of the species among the respondents.

FL was determined as follow:

$$
\mathrm{FL}=\mathrm{Nr} \mathrm{X} 100 / \mathrm{N}
$$

Where, $\mathrm{Nr}$ is the number of respondents that mention the species, and

$\mathrm{N}$ is the total number of respondents interviewed.

The voucher specimens were collected, identified scientifically and deposited at the herbarium of the Department of Plant Science, Ekiti State University, AdoEkiti, Nigeria.

Key informants that were made up of officials of Health Department of the Local Governments Authorities, Ministry of Health, Hospitals and other stakeholders, were interviewed. Also, in each community, group interviews were also carried out. Three groups, each consisted of not less than three respondents, were interviewed. This was done to attain group consensus on the suitability of the species identified at the individual level as advocated by [9].

Respondents consensus factor (RCF) was determined and used to analyse the agreement degree of the respondents' awareness of the medicinal suitability of the species.

RCF was calculated as follow:

$$
\mathrm{RCF}=\mathrm{N}_{\mathrm{x}} / \mathrm{N}_{\mathrm{Y}}
$$

Where $\mathrm{N}_{\mathrm{x}}$ is the number of groups that identify the species, and

$\mathrm{N}_{\mathrm{Y}}$ is the total number of groups interviewed.

\section{Results and Discussion}

The results obtained revealed that a total of 76 plant species that belonged to 37 families have their stems or stem barks and/ or roots extracted for medicinal purposes in the study area (Table 1). Respondents were observed to possess immense knowledge on the medicinal values of these species. Table 1 revealed that the FL value on each of the identified species was not less than 70 . This suggests that the level of awareness of the medicinal suitability of the species was high among the respondents. Similarly, the RCF values were equally high, thus corroborate the awareness level of the respondents. Apart from the fact that the RCF values were 0.90 and above in all the species, $37 \%$ of the species had RCF value of 1.00 . Previous study by [10] had asserted that the indigenous residents were quite familiar with the ethno medicinal values of species in their environment. They equally believed in their efficacies [11]. Most of these species were those used in the cure of malaria. Malaria constitutes the most prevalent disease in the study area [7].

Most of the identified species were not cultivated in the study area. Species cultivated were mostly for other purposes other than medicine. Thus the medicinal value was mostly secondary or tertiary products thus confirming the previous assertion of [6]. Most of the cultivated species (13\% of the identified species, Table 1; Species number 5, 10, 15, 19, 20, $21,27,37,45$ and 58) were done purely for provision of fruits and/or income, some for provision of shade $(3 \%$, Species number 9 and 32, Table1), some purely as ornamental (3\%, Species number 39 and 71, Table 1), fencing ( $1 \%$, Species number 68 , Table1) and timber (1\%, Species number 36 , Table 1). Some grow widely in the study area as weeds $(8 \%$, Species number $2,17,30,46,49$ and 50 , Table 1). Others grow as wildlings and were preserved by the respondents. The dependence on wildlings in the study area had been observed in previous studies by [12] and [13, 14]. Most of the uncultivated species were indigenous tree species. Numerous disincentives had been attributed to the apparent lack of interest in their cultivation by [1], [9] and [15], thus their major source of supply had been the forest. Unfortunately, the supply from the forest is no longer sustainable due to the unprecedented deforestation, increase use of fire in farm preparation and increase in land fragmentation in the study area.

Table 2 gives the checklist of the species whose stems or stem barks were extracted for the cure of major prevailing diseases in the study area. While 8 species were extracted for the treatment of asthma, 18 were used for cough, 22 for diabetes and hypertension, 12 for jaundice, 32 for malaria, 14 for sexually transmitted diseases and 11 for skin diseases. The checklist of the species whose roots were extracted for the cure of the diseases stated above is shown in Table 3. 8 species were used to cure asthma, 18 for cough, 17 for diabetes and hypertension, 9 for jaundice, 32 for malaria, 11 for sexually transmitted diseases and 7 for skin diseases.

The examination of the respondents' perception on the identified species (Table 4) revealed that the use of the species were safe and cheap. The species were considered as being readily available in the study area although some of them were rare on the abundance scale used in this study (Table 5). Results obtained (Table 5) revealed that 26, 37 and $37 \%$ of the species were observed to be very abundant, abundant and rare respectively in the study area The need for the conservation of these rare species is therefore required particularly when the extraction being examined in this study 
is annihilative and predatory. Studies have revealed that debarking often lead to the death of most plants $[10,16]$. Also, field observation revealed that debarking of the species were carried out indiscriminately and crudely executed. These indigenous species involved had been observed to regenerate poorly [10]. Quite unfortunate too, is the fact that the indigenous residents lacked requisite knowledge on their silviculture. Thus, the inference from this study revealed that the rate of regeneration of these species would be slower than the rate at which they are extracted. This situation would compromise the integrity of the mother plants, their protection would no longer be guaranteed and extraction $a d$ infinitum will not be guaranteed hence strategies that would enhance the sustainable supply of the species to both the present and future generations need to be proposed. A number of strategies proposed by $[3,6,9.10,16,17]$ would still be relevant in the study area. These, no doubt, would constitute benign strategies to sustainable health care management especially in the rural areas.

Table 1. Checklist of species identified with stem and roots being extracted in Ekiti State, Nigeria.

\begin{tabular}{|c|c|c|c|c|c|}
\hline $\mathbf{S} / \mathbf{n}$ & Species* & Vernacular Name & Family & FL & RCF \\
\hline 1 & Abrus precatorius & Oju-Ologbo & Papilionaceae & 75 & 0.90 \\
\hline 2 & Alchornea laxiflora** & Pepe, Iya & Euphorbiaceae & 82 & 0.96 \\
\hline 3 & Allanblackia floridunda & Orogbo-erin & Clusiaceae & 84 & 1.00 \\
\hline 4 & Alstonia booneei & Ahun & Apocynaceae & 84 & 1.00 \\
\hline 5 & Anacardium occidentale* & Kaasu & Anacardiaceae & 90 & 1.00 \\
\hline 6 & Anthocleista djalonensis & Shapo & Loganiaceae & 72 & 0.93 \\
\hline 7 & Anthocleista vogelii & Apara & Gentianiacaea & 74 & 0.92 \\
\hline 8 & Axonopus compressus $* *$ & Idi & Poaceae & 81 & 0.92 \\
\hline 9 & Azadirachta indica* & Dongoyaro & Meliaceae & 95 & 1.00 \\
\hline 10 & Blighia sapida* & Isin & Sapindaceae & 92 & 1.00 \\
\hline 11 & Blighia unijugata & Ako-Isin & Sapindaceae & 90 & 0.92 \\
\hline 12 & Borascus aethiopum & Agbon-Aja & Arecaceae & 70 & 0.92 \\
\hline 13 & Bridelia ferruginea & Ira & Euphorbiaceae & 97 & 1.00 \\
\hline 14 & Caesalpinia bonduc & Ayoo & Caesalpiniaceae & 92 & 0.91 \\
\hline 15 & Carica papaya* & Ibepe & Caricaceae & 93 & 1.00 \\
\hline 16 & Ceiba pentandra & Araba & Bombacaceae & 92 & 0.96 \\
\hline 17 & Chromolaena odorata** & Akintola & Asteraceae & 97 & 1.00 \\
\hline 18 & Chrysophyllum albidum & Agbalumo & Sapotaceae & 96 & 0.94 \\
\hline 19 & Citrus aurantifolia* & Osan wewe & Rutaceae & 98 & 1.00 \\
\hline 20 & Citrus aurantium* & Gayingayin & Rutaceae & 92 & 0.97 \\
\hline 21 & Citrus sinensis* & Orombo & Rutaceae & 98 & 0.97 \\
\hline 22 & Combretum mucronatum & Ogan & Combretaceae & 72 & 0.94 \\
\hline 23 & Cordial millenii & Omo & Boraginaceae & 70 & 0.92 \\
\hline 24 & Corchorus olitorius, & Ewedu & Tiliaceae & 86 & 0.92 \\
\hline 25 & Costus afer & Teteregun & Zingiberaceae & 74 & 0.94 \\
\hline 26 & Croton zambesicus & Ajekobale & Euphorbiaceae & 96 & 0.95 \\
\hline 27 & Elaeis guineensis* & Ope & Arecaceae & 97 & 0.96 \\
\hline 28 & Enantia chloranthia & Awopa & Annonaceae & 93 & 0.92 \\
\hline 29 & Entada africana & Ogurobe & Mimosaceae & 88 & 0.92 \\
\hline 30 & Euphorbia hirta** & Iroko iju & Euphorbiaceae & 73 & 0.90 \\
\hline 31 & Ficus asperifolia & Epin & Moraceae & 72 & 0.92 \\
\hline 32 & Ficus ptatyphylla* & Ogbagba & Moraceae & 71 & 0.92 \\
\hline 33 & Ficus thonningii* & Odan & Moraceae & 92 & 0.94 \\
\hline 34 & Garcinia kola & Orogbo & Clusiaceae & 94 & 1.00 \\
\hline 35 & Glyphaea brevis & Atori & Tiliaceae & 85 & 0.95 \\
\hline 36 & Gmelina arborea* & Melainia & Verbanaceae & 89 & 0.94 \\
\hline 37 & Gossypium barbadense* & Owu & Malvaceae & 96 & 1.00 \\
\hline 38 & Harungana madagascariensis & Arunje & Hypericaceae & 92 & 1.00 \\
\hline 39 & Hibiscus rosasinensis* & Adodo abisikosi & Malvaceae & 78 & 0.90 \\
\hline 40 & Jatropha curcas* & Lapalapa & Euphorbiaceae & 97 & 1.00 \\
\hline 41 & Khaya ivorensis & Oganwo & Meliaceae & 96 & 1.00 \\
\hline 42 & Lecaniodiscus cupanioides & Akika & Sapindaceae & 95 & 1.00 \\
\hline 43 & Lippie miltiflora & Efinrin gogoro & Verbanaceae & 87 & 0.97 \\
\hline 44 & Mallotus oppositifolius & Orokoro & Euphorbiaceae & 94 & 1.00 \\
\hline
\end{tabular}




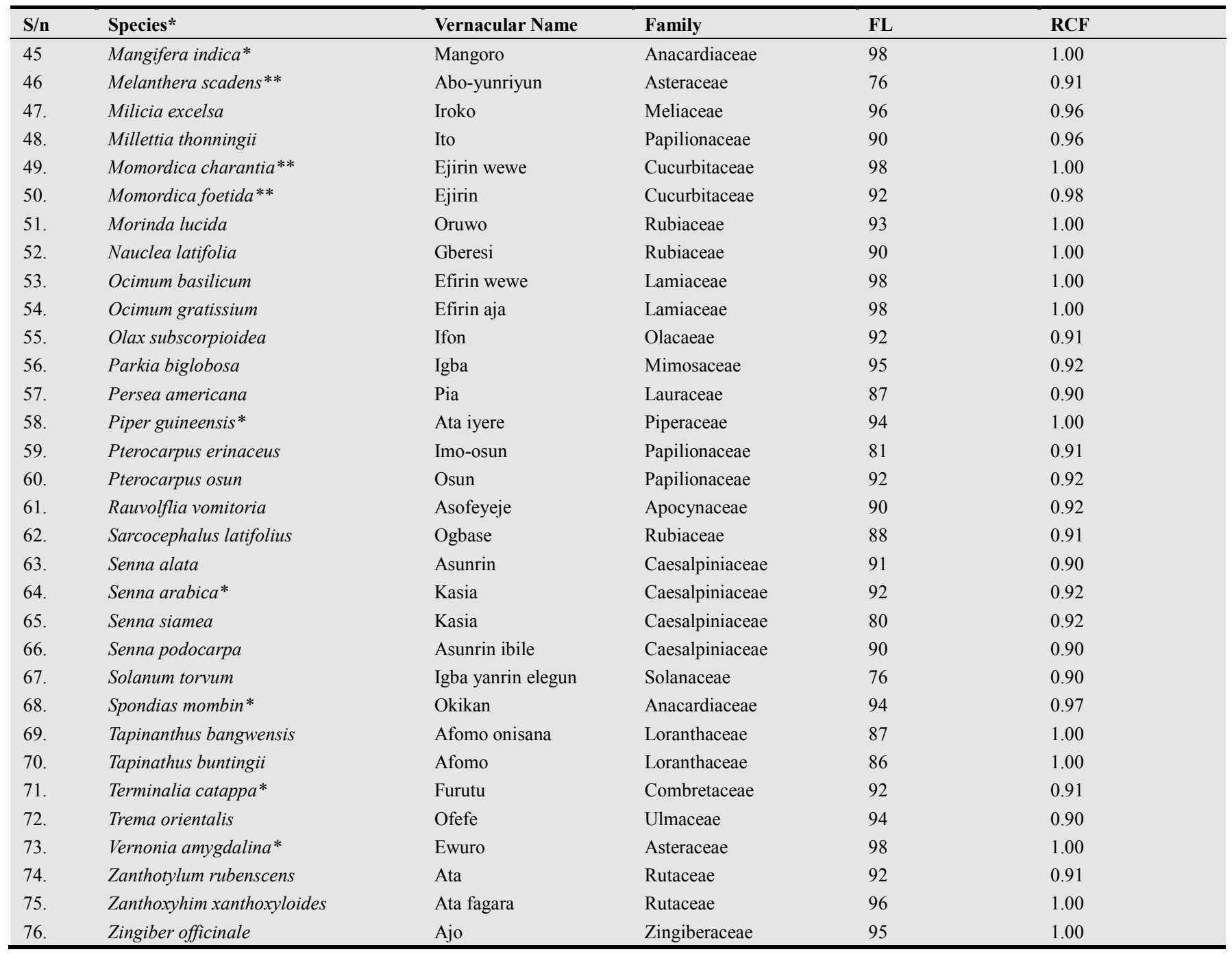

* Cultivated species, ** species that grow widely as weeds

Table 2. Checklist of species whose stems were extracted for medicinal use in Ekiti State, Nigeria.

\begin{tabular}{|c|c|}
\hline Diseases & Species extracted and used for cure \\
\hline Asthma & $\begin{array}{l}\text { A. compressus, C. pentandra, E. guineensis, E. hirta, H. rosasinensis, M. indica, P. osun, S. } \\
\text { Arabica }\end{array}$ \\
\hline Cough & $\begin{array}{l}\text { A. precaterius, A. booneei, B. sapida, C. aurantifolia, C. mucronatum, C. millenii, C. afer, E. } \\
\text { hirta, F. ptatyphylla, G. kola, J. curcas, M. indica, M. thonningii, O. gratissium, T. orientalis, } S \text {. } \\
\text { latifolius, S. mombin and Z. rubenscens }\end{array}$ \\
\hline Diabetes and hypertension & $\begin{array}{l}\text { A. occidentale, A. vogelii, B. unijugata, B. ferruginea, C. pentandra, C. aurantifolia, C. afer, } E \text {. } \\
\text { hirta, H. rosasinensis, L. multiflora, M. indica, M. foetida, M. charantia, M. lucida, P. biglobosa, } \\
\text { P. americana, R. vomitoria, S. arabica, S. mombin, V. amygdalina, T. buntingii and T. } \\
\text { bangwensis. }\end{array}$ \\
\hline Jaundice & $\begin{array}{l}\text { A. indica, C. aurantifolia, E. chloranthia, H. madagascariensis, } K \text {. ivorensis, } L \text {. cupanioides, } L \text {. } \\
\text { miltiflora, M. charantia, M. lucida, } O \text {. subscorpioidea, } R \text {. vomitoria and } T \text {. orientalis. }\end{array}$ \\
\hline Malaria & $\begin{array}{l}\text { A. floribunda, A. boonei, A. occidentales, A. compressus, A. indica, B. sapida, B. ferruginea, } C \text {. } \\
\text { pentandra, C. albidum, C. aurantifolia, C. sinensis, E, guineensis, F. thonningii, F. ptatyphylla, } \\
\text { G. kola. } \\
\text { H. madagascariensis, J. curcas, J. gossypifolia, K. ivorensis, L. cupanioides, M. indica, M. } \\
\text { thonningii, M. lucida, O. gratissiumum, O. subscorpioidea, P. biglobosa, P. angolensis, } R \text {. } \\
\text { vomitora, S. podocarpa, S. mombin, T. orientalis and V. amygdalina. }\end{array}$ \\
\hline Sexually Transmitted Diseases & $\begin{array}{l}\text { A. laxiflora, A. indica, B. ferruginea, C. potandra, C. aurantifolia, C. zambesicus, G. brevis, } O \text {. } \\
\text { basilicum, O. subscorpioidea, S. arabica, S. mombin, T. catappa, Z. rubenscens and Z. } \\
\text { xanthoxyloides }\end{array}$ \\
\hline Skin Diseases & $\begin{array}{l}\text { A. floribunda, A. djalonensis, A. indica, C. aurantifolia, E. guineensis, J. curcas, K. ivorensis, } N \text {. } \\
\text { latifolia, P. osun, S. alata and S. mombin. }\end{array}$ \\
\hline
\end{tabular}


Table 3. Checklist of species whose roots were extracted for medicinal use in Ekiti State, Nigeria.

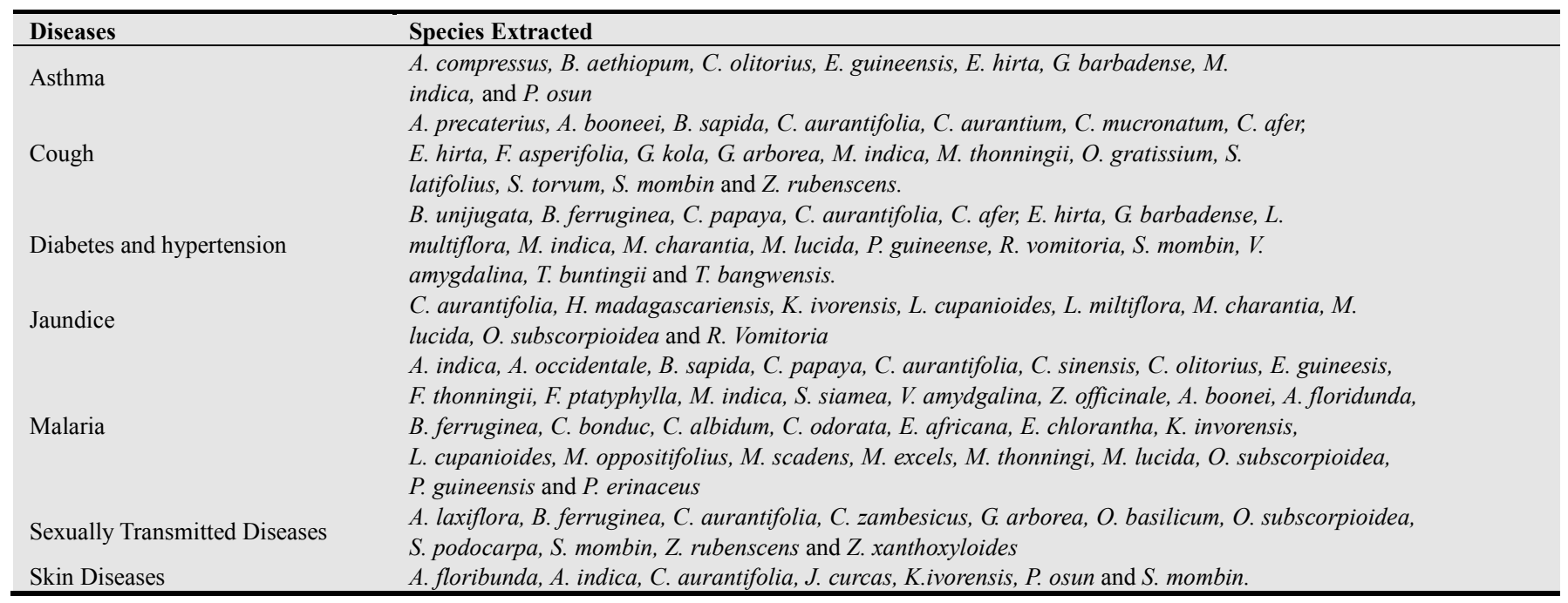

Table 4. Respondents' perception on the identified species in Ekiti State, Nigeria.

\begin{tabular}{lll}
\hline Rank & Feature & Proportion (\%) of Respondents \\
\hline 1 & Safe & 99 \\
2 & Cheap & 98 \\
3 & Ready availability & 97 \\
4 & Have little or no side effects & 96 \\
\hline
\end{tabular}

Table 5. The abundance of the identified species in Ekiti State, Nigeria.

\begin{tabular}{|c|c|c|}
\hline Abundance & Species & Proportion (\%) of the species \\
\hline Very Abundant & 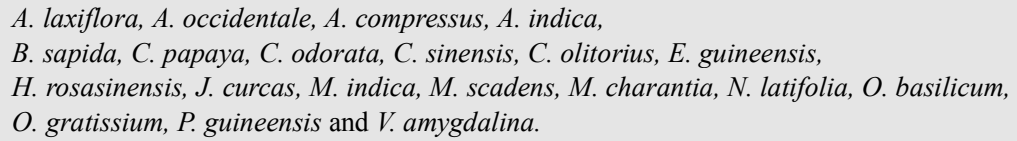 & 26 \\
\hline Abundant & $\begin{array}{l}\text { A. precaterius, A. booneei, A. djalonensis, A. vogelii, B. ferruginea, C. albidum, } \\
\text { C. aurantifolia, C. aurantium, C. afer, E. hirta, F. asperifolia, F. ptatyphylla, } \\
\text { F. thonningii, G. brevis, G. arborea, G. barbadense, M. foetida, P. biglobosa, } \\
\text { P. americana, S. alata, S. arabica, S. podocarpa, S. torvum, S. mombin, S. siamea } \\
\text { T. bangwensis, T. buntingii and T. catappa. }\end{array}$ & 37 \\
\hline Rare & $\begin{array}{l}\text { A. floridunda, B. unijugata, B. aethiopum, C. bonduc, C. pentandra, C. millenii, } \\
\text { C. mucronatum, C. zambesicus, E. chloranthia, E. africana, G. kola, } \\
\text { H. madagascariensis, K. ivorensis, L. cupanioides, L. miltiflora, M. oppositifolius, } \\
\text { M. excelsa, M. thonningii, M. lucida, O. subscorpioidea, P. erinaceus, P. osun, } \\
\text { R. vomitoria, S. latifolius, T. orientalis, Z. rubenscens, Z. xanthoxyloides and Z. officinale }\end{array}$ & 37 \\
\hline
\end{tabular}

\section{References}

[1] Kayode, J. 2004. Conservation Perception of Endangered Tree Species by Rural Dwellers of Ekiti State, Nigeria. Journal of Sustainable Forestry 19(4): 1-9.

[2] Kayode, J. and Omotoyinbo, M. A. 2008a. Conservation of Botanicals Used for Dental and Oral Healthcare in Ekiti State, Nigeria. Ethnobotanical leaflets 12, 7-18.

[3] Kayode, J. 2006. Conservation of indigenous medicinal botanicals in Ekiti State, Nigeria. Journal of Zhejiang University SCIENCE-B 7 (9): 713-718.

[4] Repetto, R. 1988. The forest for the trees: Government policies and misuse of forest resources. World Resources Institute, Washington DC., pp: 16.
[5] Lipp, F. J. 1989. Methods for ethno-phamacological fieldwork. Journal of Ethno-Pharmacology 25: 139-150.

[6] Kayode, J. 2005. Ethno botanical survey and conservation of medicinal compositae species in Benin Kingdom, Nigeria. Compositae Newsl. 42, 48-54.

[7] Molnar, A. 1989. Community Forestry: A rapid appraisal. FAO, Rome, p.60.

[8] Kayode, J. and Omotoyinbo, M. A. 2009. Ethnobotanical utilization and conservation of chewing sticks plant species in Ekiti State, Nigeria. Research Journal of Botany 4(1):1-9.

[9] Kayode, J. 2008. Survey of Plant Barks Used In Native Pharmaceutical Extraction In Yorubaland of Nigeria. Research Journal of Botany 3(1): 17-22

[10] Kayode, J. 2003. Conservation and Yoruba forest taboos. The Nigerian Field 69: 53-61. 
[11] Kayode, J. 2010. Reconciliation of the supposedly irreconcilable: Conservation and Development. $26^{\text {th }}$ Inaugural Lecture of The University of Ado-Ekiti, Ado-Ekiti, Nigeria. University of Ado-Ekiti Press, Ado-Ekiti, 57pp.

[12] Kayode, J., Christmas, E. and Kayode, G. M. 2008. Checklist and Conservation of Botanicals Used For Natality by the Okpe-Speaking People of Delta State, Nigeria. Research Journal of Medicinal Plants 2(1): 16-21.

[13] Kayode, J., Olanipekun, M. K. and Tedela, P. O. 2009. Medicobotanical studies in relation to veterinary medicine in Ekiti State, Nigeria: Checklist of botanicals species used for the treatment of poultry diseases. Ethnobotanical Leaflets 13: 40-46.
[14] Kayode, J. and Ogunleye, T. 2008. Checklist and Status of Plant Species Used as Spices in Kaduna State of Nigeria. Research Journal of Botany, 3 (1), 35-40

[15] Cunningham, A. B. 1988. Collection of wild plant food in Tembe Thonga society. A guide to Iran age gathering activities. Ann. Natal Museum 29: 437-446.

[16] Kayode, J. 2007. Conservation Implications of Timber Supply Pattern in Ekiti State, Nigeria. Research Journal of Forestry 1(2): $86-90$.

[17] Kayode, J. and Omotoyinbo, M. A. 2008b. Cultural Erosion and biodiversity: Conserving chewing stick knowledge in Ekiti State Nigeria. African Scientist 9(1): 41-51. 